\title{
A brief overview of antitumoral actions of bruceine D
}

\author{
Zi Wayne $\operatorname{Sin}^{1}$, Vipul Bhardwaj ${ }^{2}$, Amit Kumar Pandey ${ }^{3}$, Manoj Garg²* \\ ${ }^{1}$ Department of Biological Sciences, National University of Singapore, Singapore 117600, Singapore \\ ${ }^{2}$ Amity Institute of Molecular Medicine and Stem cell Research (AIMMSCR), Amity University Uttar Pradesh, Noida 201313, \\ India \\ ${ }^{3}$ Amity Institute of Biotechnology, Amity University Haryana, Manesar, Haryana 122413, India
}

*Correspondence: Manoj Garg, Amity Institute of Molecular Medicine and Stem cell Research (AIMMSCR), Amity University Uttar Pradesh, Noida 201313, India. mgarg@amity.edu; nuscsimg@gmail.com

Academic Editor: Gautam Sethi, National University of Singapore, Singapore

Received: May 30, 2020 Accepted: June 30, 2020 Published: August 31, 2020

Cite this article: Sin ZW, Bhardwaj V, Pandey AK, Garg M. A brief overview of antitumoral actions of bruceine D. Explor Target Antitumor Ther. 2020;1:200-17. https://doi.org/10.37349/etat.2020.00013

\begin{abstract}
Cancer remains the second leading cause of mortality globally. In combating cancer, conventional chemotherapy and/or radiotherapy are administered as first-line therapy. However, these are usually accompanied with adverse side effects that decrease the quality of patient's lives. As such, natural bioactive compounds have gained an attraction in the scientific and medical community as evidence of their anticancer properties and attenuation of side effects mounted. In particular, quassinoids have been found to exhibit a plethora of inhibitory activities such as anti-proliferative effects on tumor development and metastasis. Recently, bruceine D, a quassinoid isolated from the shrub Brucea javanica (L.) Merr. (Simaroubaceae), has come under immense investigation on its antineoplastic properties in various human cancers including pancreas, breast, lung, blood, bone, and liver. In this review, we have highlighted the antineoplastic effects of bruceine $\mathrm{D}$ and its mode of actions in different tumor models.
\end{abstract}

\section{Keywords}

Cancer, bruceine D, epithelial-to-mesenchymal transition, cancer stem cells, metastasis, apoptosis, antiinflammatory, PI3K/AKT/ERK pathway

\section{Introduction}

Cancer can result from uncontrolled cellular proliferation and growth that forms an abnormal mass of tissue known as a tumor. It can be caused by a plethora of risk factors such as genetic mutation due to exposure to radiation or carcinogens, epigenetics, viral infection, and reactivation [1-5]. According to the World Health Organisation, cancer is the second leading cause of global mortality in 2018 [6]. It is therefore not surprising that cancer research remains at the cynosure of the scientific community. Chemotherapy and radiotherapy are commonly administered for the treatment of human malignancies with temporary relief and adverse side effects such as nausea, vomiting, and hair loss, drastically diminishing the quality of life of cancer patients $[3,7]$. In the past decade, research on natural bioactive compounds derived from plants and microbes have

(C) The Author(s) 2020. This is an Open Access article licensed under a Creative Commons Attribution 4.0 International License (https://creativecommons.org/licenses/by/4.0/), which permits unrestricted use, sharing, adaptation, distribution and reproduction in any medium or format, for any purpose, even commercially, as long as you give appropriate credit to the original author(s) and the source, provide a link to the Creative Commons license, and indicate if changes were made. 
been gaining traction [8-13]. They can attenuate the side effects of conventional cancer treatment [14]. Importantly, these natural compounds possess anti-cancer effects [14-22]. In the field of cancer, natural products or their derivatives constitute approximately $49 \%$ of small molecule drugs approved by the United States Food and Drug Administration (FDA) from the 1940s to the end of 2014 [23]. As of 2019, 7 out of 48 newly approved drugs by the US FDA were inspired based on natural products [24]. While these drugs were not naturally derived compounds per se, it still highlighted the importance of natural bioactive compounds in novel drug development.

Brucea javanica (L.) Merr. (Simaroubaceae) is a shrub that is widely distributed in most of Asia and Australia [25]. The fruits and seeds of Brucea javanica have long been used as Chinese medicine in treating various diseases like dysentery, malaria, and inflammatory diseases [25, 26]. Of particular interest are the quassinoids isolated from the fruits of Brucea javanica. There are currently 52 known quassinoids such as brusatol, dehydrobruceine D, and bruceine D (BD) isolated from the fruits and seeds of Brucea javanica [27]. These quassinoids have been shown to exhibit a wide range of inhibitory effects, including anti-viral effects against plant-based viruses like tobacco mosaic virus and potato virus $Y$ to anti-proliferative and cytotoxic effects on various tumor cells like lung cancer tumors and breast cancer tumors [28-34]. In this review, we will specifically be summarizing the antineoplastic effects of BD on various cancer cell lines from the current literature.

\section{Chemistry of BD}

$\mathrm{BD}$ is a quassinoid with molecular formula $\mathrm{C}_{20} \mathrm{H}_{26} \mathrm{O}_{9}$. Many quassinoids have been found to exhibit tumoricidal activity and anticarcinogenic properties, with $\mathrm{BD}$ having found to exhibit cytotoxic effects and anti-proliferative effects against pancreatic cancer, breast cancer, lung cancer, leukemia, osteosarcoma, and hepatocellular carcinoma [35]. The structure-activity relationship of the inhibitory effects of some quassinoids, including BD, has only been elucidated very recently. Here, we will give particular focus to the structure-activity relationship of the antineoplastic effects of quassinoids. The substitution of oxygen-groups, methyl or - $\mathrm{CH}_{2} \mathrm{OH}$, glycosyl, $\alpha, \beta$-unsaturated ketone group, and olefenic bond was found to be pertinent in influencing the antineoplastic actions of quassinoids. Various modifications to the aforementioned chemical groups have been investigated and the extent of the anti-proliferative activity of the tested quassinoids against pancreatic cancer and breast cancer cell lines varied accordingly [29, 30, 36, 37].

\section{Antineoplastic effects of BD in human malignancies}

Anti-proliferative and pro-apoptotic effects of BD

It is known that dysregulation of cell cycle leading to uncontrolled cell proliferation and apoptosis evasion are hallmarks of all cancer cell types [29, 38-41]. Indeed, through various cell proliferation assays like Sulforhodamine B assay, MTT assay, and Cell Counting Kit 8 assay, BD has been established to exhibit anti-proliferative properties against pancreatic cancer cells (PANC-1, SW1990, CAPAN-1) [29, 37], lung cancer cells [A549, NCI-H292, non-small cell lung cancer (NSCLC) H460] [28, 42, 43], chronic myeloid leukemia (K562) [44], breast cancer cells (MDA-MB-231) [30], hepatocellular carcinoma cells (Bel7404, HepG2, Hep3B, Huh7, PLC) [45, 46], and osteosarcoma cells (MNNG/HOS, U-2OS, MG-63, Saos-2) [47]. In all of the investigated cancer cell lines, there was increased activation of pro-apoptotic proteins like B-cell lymphoma 2 (Bcl-2) associated protein (Bax) and Bak and downregulation of anti-apoptotic proteins like Bcl-2 and myeloid cell leukemia 1 (Mcl-1) [48], all of which are tightly linked to cellular proliferation and apoptotic pathways like phosphatidylinositol 3-kinase (PI3K)/protein kinase B (AKT)/mammalian target of Rapamycin (mTOR), c-Jun N-terminal kinase (JNK), mitogen-activated protein kinases (MAPK), and canonical Wnt signaling pathways (Figure 1) [49-52]. The anti-proliferative effects of BD and $\mathrm{IC}_{50}$ values on the aforementioned in vitro cancer cell lines and in vivo cancer models are summarized in Table 1 and Table 2 , respectively. It has been noticed that the anti-proliferative effect of BD varied in a time-dependent and dosedependent manner in all of the experiments. Importantly, no significant toxicity of BD was observed against normal control cell lines. 


\section{Effect of BD against triple-negative breast cancer (TNBC)}

TNBC is characterized by the absence or down-regulation of estrogen receptors, progesterone receptors, and human epidermal growth factor 2 receptors [53-55]. Due to its aggressiveness, malignancy, and distant recurrence, TNBC is usually accompanied by a poor clinical prognosis and short life expectancy $[55,56]$. To date, the best therapeutic treatment for TNBC is restricted only to chemotherapy, surgical tumor removal, and limited clinical drugs which are still being evaluated in clinical trials [55, 57-59]. It is therefore imperative to uncover new sources of adjuvant or stand-alone treatment for TNBC, be it to combat TNBC or to alleviate discomfort from standard chemotherapy and surgical procedures. Luo et al. [30], have investigated the inhibitory effects of BD on MDA-MB-231 (TNBC) cells. They investigated the role of PI3K/AKT signaling in tumor metastasis with low doses of BD that does not affect cell viability as it was previously reported that the PI3K/AKT signaling pathway was implicated, albeit in colorectal cancer cells [60]. It was found that BD significantly decreased PI3K expression and AKT phosphorylation in a dose-dependent manner while total AKT levels remained constant, leading them to conclude that the PI3K/AKT signaling pathway was implicated in tumor metastasis of TNBC. While the role of PI3K/AKT signaling in cell proliferation was not clearly established in the study, it has long known that the PI3K/AKT signaling pathway regulates cellular proliferation, cell cycle, and apoptosis. Its dysregulation is also implicated in various in vitro cancer models, where PI3K and it's downstream molecular targets are constitutively active, leading to uninhibited cell proliferation and cell growth [61]. Further, it was also found that the PI3K/AKT/mTOR pathway is frequently activated in TNBC [62]. With knowledge from existing literature, there is a high possibility that anti-proliferative and pro-apoptotic effects of the BD on TNBC could be mediated through the PI3K/AKT pathway. However, we can only hypothesize at best since it was never explicitly investigated in the context of proliferation and apoptosis.

\section{Effect of BD against pancreatic adenocarcinoma}

Pancreatic adenocarcinoma comprises $95 \%$ of the diagnosed pancreatic cancer cases, with other cases being rarer forms of neuroendocrine cancers $[63,64]$. Patients with pancreatic cancer have worse prognosis due to its aggressive, metastatic, and drug-resistance nature $[65,66]$. Chemotherapeutic agents such as gemcitabine, 5-fluorouracil, and capecitabine are commonly administered for patients with pancreatic adenocarcinoma. To date, gemcitabine remains the chemotherapeutic agent of choice [64,67], but acquiredgemcitabine resistance of pancreatic adenocarcinoma cells is the unsolved mystery [68-70]. Natural bioactive compounds like camptothecin (DNA topoisomerase I poison) could also be used as a chemotherapeutic agent but it showed only low therapeutic efficacy with severe toxicity [71]. It has been previously demonstrated that Brucea javanica fruit extract was able to exert cytotoxic and pro-apoptotic effects against pancreatic adenocarcinoma cell lines PANC1, SW1990, and CAPAN-1 [37, 72]. In a follow-up study in 2009 by the same team, BD was used directly instead of Brucea javanica fruit extract. It was shown that there was a BD dose-dependent apoptogenic effect on PANC-1 cells following Annexin V-PI double staining. Western blot analysis was also congruent with the results of the Annexin V-PI assay, whereby induction of caspase 3 and 8, enhancement of pro-apoptotic protein Bak, and decrease in anti-apoptotic protein Bcl-2 were seen. Further investigation elucidated that BD-induced cellular apoptosis was mediated through the necessary activation of the p38-MAPK signaling pathway as prior incubation with p38-MAPK inhibitor SB203580 attenuated caspase activation and DNA fragmentation.

MAPK participates in signaling pathways that are crucial for the maintenance of normal cellular processes like cell-cycle progression, cell proliferation, and apoptosis [73-77]. p38-MAPK constitutes one of the four subgroups within the MAPK family and respond to a wide range of extracellular stimuli such as stress or growth factor stimulation [78]. It is known that p38-MAPK activation could induce apoptosis and cell-cycle arrest, leading to tumor suppression. Conversely, inactivation, or down-regulation of p38-MAPK increases the tumorigenic potential of cells as DNA damage accumulates with each successive cell cycle [79]. Downstream molecular targets of p38-MAPK include c-Jun, signal transducers and activator of transcription 1 (STAT1), and p53 proteins amongst an abundance of other proteins, all of which are involved in regulating the balance between cellular proliferation and apoptosis [79-84]. 
It was proposed in the study that BD could have participated in both extrinsic and intrinsic apoptotic pathways. In the intrinsic pathway, BD would have acted as an extracellular stress signal which activates the p38-MAPK pathway. In the extrinsic pathway, BD would have acted as a ligand to membrane death receptors. No discrimination was made between those two apoptotic pathways when it came to examining the expression of caspase 3, caspase 8, and caspase 9 is known to be implicated in both mitochondrial-mediated apoptosis and receptor-mediated apoptosis [85].

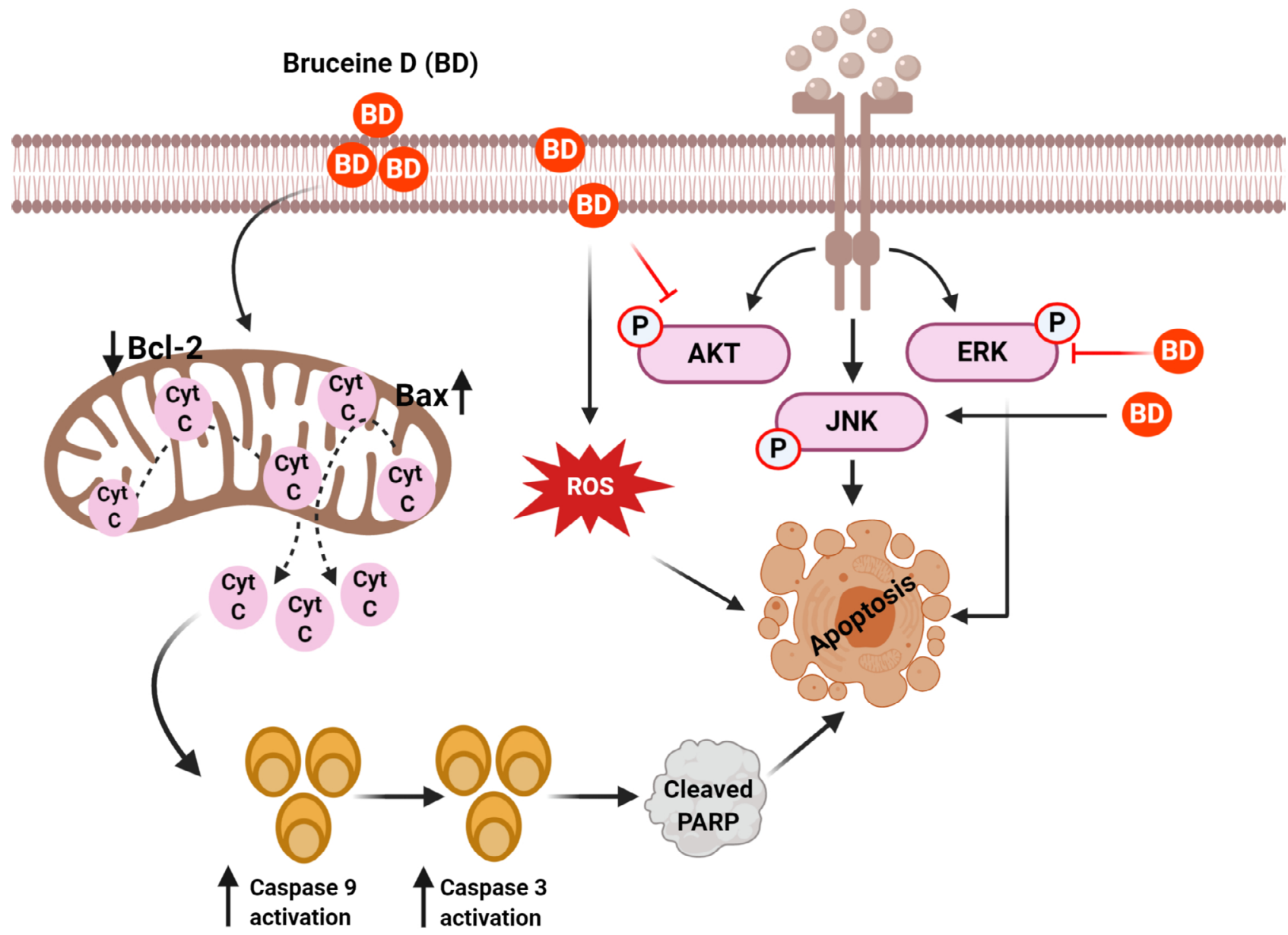

Figure 1. Mechanisms of BD for its anticancer effect in human cancers. BD treatment suppressed the AKT/ERK and activate the JNK signaling cascades to induce apoptosis of cancer cells. BD caused apoptosis of cancer cells by regulating ROS and mitochondrial proteins

\section{Effect of BD against chronic myeloid leukemia}

Chronic myeloid leukemia is a myeloproliferative malignancy that is usually caused by a chromosomal rearrangement event between chromosome 22 and chromosome 9 to form the Philadelphia chromosome $[86,87]$. It is characterized by over-expression of a fusion oncoprotein BCR-ABL1 that acts as a constitutively active defective tyrosine kinase, implicating downstream signaling pathways such as PI3K/AKT/mTOR, Janus kinase (JAK)/STAT and Ras protein family (Ras)/mitogen-activated protein kinase kinase (MEK), all of which are crucial in maintaining normal cellular proliferation and apoptosis $[86,88]$. Conventional therapeutic agents like imatinib, nilotinib, dasatinib, ponatinib, and bosutinib, therefore, act as tyrosine kinase inhibitors to prevent constitutive activation of the receptor tyrosine kinases in CML [86, 89-91].

BD was found to induce cellular apoptosis via the intrinsic mitochondrial-apoptotic pathway to K562 cells in a time-dependent manner [44,80]. The intrinsic apoptosis pathway is characterized by a loss of membrane potential leading to the release of cytochrome c (cyt c) to the cytosol. Cyt c then binds to apoptotic peptidase activating factor 1 and caspase- 9 to form an apoptosome, which cleaves caspase 3 to trigger apoptosis [44, 92]. It was postulated that the PI3K/AKT and Ras/Raf/extracellular signal-regulated kinase 
(ERK) pathways were upstream targets of BD in the study. Indeed, phosphorylated AKT and phosphorylated ERK levels were attenuated in cells treated with BD. However, since ERK activation need not always lead to pro-survival signals as ERK activation was reported to exhibit pro-apoptotic functions [93, 94], ERK activity must be interpreted in context. It remains unclear whether BD acted as a receptor tyrosine kinase inhibitor prior to PI3K and ERK activation or as an activator of phosphatases to PI3K and ERK.

Table 1. Details of the anticancer efficacy of BD in several human malignancies using in vitro models

\begin{tabular}{|c|c|c|c|c|c|c|}
\hline Cancer type & Cell lines & $\begin{array}{l}\text { Anti-cancer } \\
\text { efficacy }\end{array}$ & Mode of action & $\begin{array}{l}\text { Concentration } \\
(\mu \mathrm{M})\end{array}$ & $\begin{array}{l}\text { IC }_{50} \text { (anti- } \\
\text { proliferation) }\end{array}$ & References \\
\hline \multirow[t]{7}{*}{ NSCLC } & A549 & \multirow[t]{3}{*}{ Anti-proliferative } & \multirow{3}{*}{$\begin{array}{l}\uparrow R O S, \uparrow p J N K, \\
\uparrow A p o p t o s i s ; \\
\uparrow L C 3-I I, \\
\uparrow \text { Autophagy }\end{array}$} & \multirow[t]{3}{*}{$0-40$} & A549: 17.89 (48 h) & \multirow[t]{3}{*}{ [28] } \\
\hline & \multirow[t]{2}{*}{$\mathrm{NCl}-\mathrm{H} 292$} & & & & NCI-H292: 14.42 & \\
\hline & & & & & $(48 \mathrm{~h})$ & \\
\hline & A549 & \multirow[t]{4}{*}{ Anti-proliferative } & \multirow{4}{*}{$\begin{array}{l}\text { A549, H460: } \\
\uparrow p J N K, \downarrow B c l-2, \\
\uparrow B A X, \uparrow c a s p a s e \\
3 \text { and PARP, } \\
\uparrow A p o p t o s i s\end{array}$} & \multirow[t]{4}{*}{$0-12.5$} & A549: $0.6(48 \mathrm{~h})$ & \multirow[t]{4}{*}{ [41] } \\
\hline & $\mathrm{H} 460$ & & & & H460: $0.5(48$ h) & \\
\hline & PC9 & & & & PC9: $1.0(48$ h) & \\
\hline & H1975 & & & & H1975: 2.7 (48 h) & \\
\hline \multirow{3}{*}{$\begin{array}{l}\text { Pancreatic } \\
\text { adenocarcinoma }\end{array}$} & PANC1 & \multirow[t]{3}{*}{ Anti-proliferative } & \multirow{3}{*}{$\begin{array}{l}\text { PANC1: } \uparrow p 38- \\
\text { MAPK, } \downarrow \text { Bcl-2, } \\
\uparrow B A X, \uparrow \text { caspase } \\
3 \text { and } 8\end{array}$} & \multirow[t]{3}{*}{$<0.1->30$} & PANC1: 2.53 (72 h) & \multirow[t]{3}{*}[29,37]{} \\
\hline & SW1990 & & & & SW1990: 5.21 (72 h) & \\
\hline & CAPAN-1 & & & & CAPAN-1: 1.35 (72 h) & \\
\hline \multirow[t]{2}{*}{$\begin{array}{l}\text { Chronic Myeloid } \\
\text { Leukemia }\end{array}$} & \multirow[t]{2}{*}{ K562 } & \multirow[t]{2}{*}{ Anti-proliferative } & $\begin{array}{l}\downarrow \text { pAKT and } \\
\text { pERK; }\end{array}$ & \multirow[t]{2}{*}{$0-12$} & $6.37 \pm 0.39(72 \mathrm{~h})$ & \multirow[t]{2}{*}{ [44] } \\
\hline & & & $\begin{array}{l}\downarrow \Psi \mathrm{m}, \uparrow \text { caspase } \\
3 \text { and } 9, \uparrow \text { PARP }\end{array}$ & & & \\
\hline \multirow[t]{3}{*}{ TNBC } & \multirow[t]{3}{*}{ MDA-MB-231 } & Anti-proliferative & $\downarrow \mathrm{PI} 3 \mathrm{~K}, \downarrow \mathrm{pAKT}$ & \multirow[t]{3}{*}{$0-100$} & \multirow{3}{*}{$\begin{array}{l}5.84(48 \mathrm{~h}) ; 2.364 \\
(72 \mathrm{~h})\end{array}$} & \multirow[t]{3}{*}{ [30] } \\
\hline & & Anti-invasive & $\uparrow$ E-cadherins, & & & \\
\hline & & Anti-migration & $\begin{array}{l}\beta \text {-catenin, } \\
\text { partial EMT } \\
\text { reversal }\end{array}$ & & & \\
\hline \multirow[t]{5}{*}{ Osteosarcoma } & MNNG/HOS & Anti-proliferative & \multirow{3}{*}{$\begin{array}{l}\downarrow \text { pSTAT3, } \\
\downarrow \text { Cyclin D1, } \\
\text { CDK4, CDK2, } \\
\uparrow A \text { Apoptosis; }\end{array}$} & \multirow[t]{5}{*}{$0-20$} & MNNG/HOS: 0.9 & \multirow[t]{5}{*}[47]{} \\
\hline & U-2OS & Anti-invasive & & & $(48 \mathrm{~h})$ & \\
\hline & MG-63 & Anti-migration & & & U-2OS: 0.05 (48 h) & \\
\hline & \multirow[t]{2}{*}{ Saos-2 } & \multirow[t]{2}{*}{ Anti-CLC } & \multirow{2}{*}{$\begin{array}{l}\downarrow \text { pSTAT3, } \\
\downarrow \text { CD133, SOX2, } \\
\text { Oct-4, Nanog }\end{array}$} & & MG-63: 0.65 (48 h) & \\
\hline & & & & & Saos-2: $0.51(48 \mathrm{~h})$ & \\
\hline Hepatocellular & Huh7 & Anti-proliferative & $\uparrow$ Proteasome, & $0-20$ & Approx. 2.5 (48 h) & {$[45]$} \\
\hline carcinoma & Нер3В & & $\begin{array}{l}\downarrow \text { lotal } \beta \text {-catenin, } \\
\downarrow \text { Active } \\
\beta \text {-catenin, } \\
\downarrow \text { JAG } 1, \downarrow N I C D, \\
\uparrow A \text { Apoptosis }\end{array}$ & & & \\
\hline & Bel7404 & Anti-proliferative & $\downarrow \mathrm{miR}-95$ & $0.25-1.5$ & Bal7407: 1.0 (72 h) & {$[46]$} \\
\hline & HepG2 & & $\uparrow$ CUGBP2, & & HepG2: $~ 0.8(72$ h) & \\
\hline & Нер3В & & & & Hep3B: $\sim 0.75$ (72 h) & \\
\hline & Huh7 & & & & Huh7: 0.6 (72 h) & \\
\hline & PLC & & & & PLC: $\sim 0.8(72 \mathrm{~h})$ & \\
\hline
\end{tabular}

$\Psi_{\mathrm{m}}$ : mitochondrial membrane potential; CD133: prominin-1; CDK2: cyclin dependent kinase 2; CUGBP2: Elav-like family member 2; JAG1: Jagged1; LC3-II: autophagy marker; Nanog: homeobox protein NANOG; NICD: cleaved intracellular domain of Notch receptor; Oct-4: octamer-binding transcription factor 4 (also known as POU5F1); PARP: poly (ADP-ribose) polymerase; p38-MAPK: p38 mitogen-activated protein kinases; pAKT: phosphorylated protein kinase B; pERK: phosphorylated extracellular signal regulated kinase; pJNK: phosphorylated c-Jun N-terminal kinase; pSTAT3: phosphorylated signal transducer and activator of transcription 3; SOX2: SRY (sex determining region Y)-box 2; CDK4: cyclin-dependent kinase 4; EMT: epithelialmesenchymal transition; miR-95: microRNA-95 
Table 2. Details of the anticancer efficacy of BD in several human malignancies using in vivo models

\begin{tabular}{|c|c|c|c|c|c|c|c|c|}
\hline Cancer type & $\begin{array}{l}\text { Model } \\
\text { used }\end{array}$ & Dose & Duration & $\begin{array}{l}\text { Measurement } \\
\text { frequency }\end{array}$ & $\begin{array}{l}\text { Route of } \\
\text { administration }\end{array}$ & $\begin{array}{l}\text { Observed } \\
\text { effects }\end{array}$ & $\begin{array}{l}\text { Mode of } \\
\text { action }\end{array}$ & References \\
\hline NSCLC & $\begin{array}{l}\text { A549 } \\
\text { cells in } \\
\text { BALB/c- } \\
\text { nu mice }\end{array}$ & $\begin{array}{l}40 \mathrm{mg} / \\
\mathrm{kg} / \mathrm{day}\end{array}$ & 15 days & Every 2 days & $\begin{array}{l}\text { Intraperitoneal } \\
\text { injection }\end{array}$ & $\begin{array}{l}\downarrow \text { Tumour } \\
\text { growth }\end{array}$ & $\begin{array}{l}\uparrow p J N K, \\
\uparrow \text { caspase } 9 \\
\uparrow A p o p t o s i s ; \\
\uparrow L C 3-I I, \\
\uparrow A u t o p h a g y\end{array}$ & [28] \\
\hline Osteosarcoma & $\begin{array}{l}\text { MNNG/ } \\
\text { HOS cells } \\
\text { in BALC/ } \\
\text { c-nu mice }\end{array}$ & $\begin{array}{l}2.5 \mathrm{mg} / \\
\mathrm{kg} / 2 \\
\text { days; } \\
5.0 \mathrm{mg} / \\
\mathrm{kg} / 2 \text { days }\end{array}$ & 12 days & Every 2 days & $\begin{array}{l}\text { Intraperitoneal } \\
\text { injection }\end{array}$ & $\begin{array}{l}\downarrow \text { Tumour } \\
\text { size } \\
\downarrow \text { Tumour } \\
\text { weight }\end{array}$ & $\begin{array}{l}\downarrow \text { PSTAT3, } \\
\downarrow \text { MMP2 and } \\
\text { MMP9, } \downarrow \text { Ki67 }\end{array}$ & [47] \\
\hline $\begin{array}{l}\text { Hepatocellular } \\
\text { carcinoma }\end{array}$ & $\begin{array}{l}\text { Huh7 } \\
\text { cells in } \\
\text { BALC/c- } \\
\text { nu mice }\end{array}$ & $\begin{array}{l}0.75 \mathrm{mg} / \\
\mathrm{kg} / \mathrm{day} ; \\
1.5 \mathrm{mg} / \\
\mathrm{kg} / \mathrm{day}\end{array}$ & 10 days & Daily & $\begin{array}{l}\text { Intravenous tail } \\
\text { vein injection }\end{array}$ & $\begin{array}{l}\downarrow \text { Tumour } \\
\text { growth }\end{array}$ & $\begin{array}{l}\uparrow \text { Proteasome, } \\
\downarrow \text { Total } \\
\beta \text {-catenin, } \\
\downarrow \text { Active } \\
\beta \text {-catenin, } \\
\downarrow \text { JAG1, } \\
\downarrow N I C D, \\
\uparrow A \text { Apoptosis }\end{array}$ & [45] \\
\hline
\end{tabular}

MMP2: matrix metalloproteinase-2 (gelatinase A); MMP9: matrix metallopeptidase 9 (gelatinase B)

\section{Effect of BD against NSCLC}

NSCLC constitute the majority of lung cancer cases in the world [95-100]. The effects of BD on the NSCLC cell lines A549, NCI-H292, and $\mathrm{H} 460$ has been investigated by different groups and reported that BD-induced intrinsic cellular apoptosis was mediated through the MAPK/JNK pathway [28, 42, 43]. Similar to p38-MAPKs, JNKs belong to the MAPK superfamily and regulate important biological processes like cellular proliferation and apoptosis. Phosphorylation of JNK will translocate it to the nucleus, where it phosphorylates c-Jun and forms activator protein 1, a transcription factor that is involved in the expression of pro-apoptotic proteins in both extrinsic and intrinsic apoptosis pathways [101]. In addition to apoptosis, BD was able to enhance autophagic flux in cell lines A549 and NCI-H292, another cellular process that can inhibit tumorigenesis and cancerous cell proliferation $[28,43]$.

Furthermore, it was highlighted that JNK activation and subsequent cellular apoptosis and autophagy was mediated mostly through BD-induced reactive oxygen species (ROS) production. Pre-treatment of cells with $\mathrm{N}$-acetylcysteine, an antioxidant, before $\mathrm{BD}$ administration abolished apoptosis and autophagy almost entirely [28]. ROS are constantly being produced by cellular metabolic processes, and they are removed by antioxidant proteins [102]. Failure to maintain the dynamic equilibrium between ROS production and ROS elimination would result in oxidative stress to the cell $[102,103]$. To this effect, ROS can activate different MAPK pathways to elicit different cellular responses. Herein, it is widely recognized that ROS oxidizes Trx (an antioxidant protein) to dissociate from apoptosis signal-regulating kinase 1 (ASK-1) (MAP3K5, another member of the MAPK family). The active ASK-1 would then activate downstream JNK pathways $[102,103]$. BD also demonstrated the same effects in vivo, at least for A549 and NCI-H292 cell lines [28, 43].

\section{Effect of BD against osteosarcoma}

Osteosarcoma is a relatively rare type of primary bone malignancy that occurs mostly during adolescence and young adulthood [104]. While tumors can be treated efficiently with traditional chemotherapy, increasingly resistant cancer stem cells (CSCs) pose a significant threat to recurrent cancer progression [104]. This highlights the need to develop agents that could target CSCs specifically in addition to proliferating tumors [105-108]. In this light, the effect of BD against osteosarcoma cell lines MNNG/HOS and U-2OS was explored by Wang et al. [47]. It was demonstrated that BD-induced inhibition of cellular proliferation was through modulating key proteins involved in cell cycle progression and promoting apoptosis. There was significant downregulation of Cyclin D1, CDK4, and CDK2 expression. Cyclin D1 is vital in regulating the transition from G1 to S phase, and over-expression of cyclin D1 has been associated with tumorigenesis [47]. Increased pro- 
apoptotic protein expression was also detected for cells treated with BD. The repression of the JAK2/STAT3 signaling pathway was seen to be implicated for cells with BD treatment, with particular attention being paid to the upregulation of phosphatase Tyrosine-protein phosphatase non-receptor type 6 (SHP1) that negatively regulates STAT3 [47].

Most notably however was that BD treatment was able to decrease the proportion of stem-like osteosarcoma cells and impaired the self-renewal ability of osteosarcoma stem cells [47]. This was quantified through the downregulation of biomarkers via flow cytometry and Western blot analysis of multiple CSC markers like CD133 and stem cell markers like SOX2, Oct-4, and Nanog (Figure 2) [47].

\section{Bruceine D (BD)}
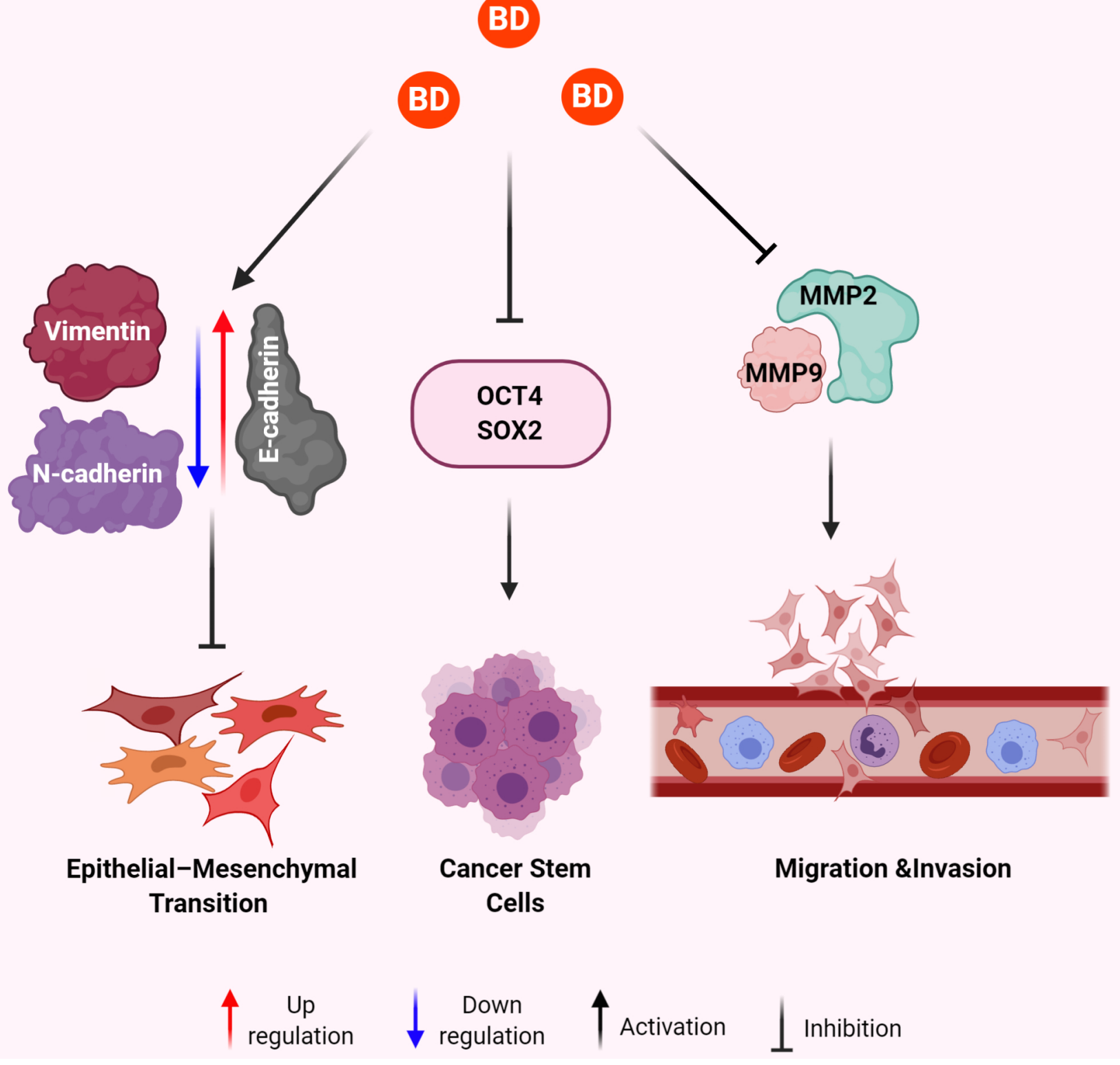

Figure 2. Mechanisms of BD for anti-metastatic effect in human malignancies. BD results in increased expression of E-cadherin and decreased expression of vimentin and $\mathrm{N}$-cadherin leading to decreased EMT. BD treatment leads to decreased expression of OCT4 and SOX2 to eradicate the CSCs. BD exposure attenuates the expression of MMP2 and MMP9 to inhibit migration and invasion of cancer cells

\section{Effect of BD against hepatocellular carcinoma (HCC)}

HCC is one of the most common malignancies in the world [109-111]. To date, only a few targeted therapies have found to be effective against HCC and natural products may also exhibit their diverse anti-cancer 
actions against this malignancy [112-114]. Hence, there is a need for the development of cheaper and more encompassing therapeutic options. Two modes of action of BD-induced inhibition cellular proliferation were uncovered. In one study, BD suppresses proliferation via $\beta$-catenin/JAG1 pathways [45]. BD was demonstrated, both in vivo and in vitro, to induce proteasomes that degraded $\beta$-catenin and active $\beta$-catenin and pro-survival proteins from the transcriptional activities of active $\beta$-catenin from the canonical Wnt $\beta$ catenin signaling pathway [45], which includes the JAG1 protein [115]. JAG1 in turn acts as a ligand to the canonical Notch signaling pathway, in which over-expression of JAG1 and/or aberrant activation of the Notch pathway is associated with cancer [116].

In a separate study using Hep3B, PLC, HepG2, Huh7, and Bel7407, BD suppressed cellular proliferation via miR-95 expression and induction of pro-apoptotic protein CUGBP2 [46]. There is growing evidence that miRNAs are capable of effecting oncogenic or tumor-suppressive functions, dysregulation of which have significant influence over tumorigenesis and its underlying cellular processes [117]. The oncogenic function of miR-95 is implicated in a wide range of cancers like osteosarcoma, recurrent NSCLC, and HCC, where down-regulation of miR-95 has been found to suppress tumor growth $[38,118]$. BD was suggested as a negative regulator of the promoter of miR-95, whereby BD treatment decreased miR-95 expression. Using bioinformatics analysis via TargetScan and PicTar, it was further identified that the 3' untranslated region of CUGBP2 mRNA was a direct downstream target for miR-95, and miR-95 binding interfered with CUGBP2 translation [119]. While CUGBP2 was previously shown to induce apoptosis in colon cancer cells via active stabilization and translation inhibition of pro-survival protein Mcl-1 [120], the mechanism of CUGBP2 within HCC has not been elucidated.

\section{Anti-metastatic effects of BD}

Metastasis can be defined as the spread of neoplastic tissue to organs and systems beyond the origin of a benign tumor, usually resulting in the formation of new tumors [121-123]. It is an extremely complex process that involves a sequential series of steps known as the invasion-metastasis [124-129]. In brief, metastasis begins with the invasion of cancer cells into the local extracellular matrix, followed by penetration of endothelium basal membrane and entry into blood vessels and/or lymph nodes, usually ending with extravasation into the surrounding tissue of a distant organ [128-133]. In particular, it was proposed that EMT is paramount to the start of the cascade. It is worth noting that EMT is not exclusive only to tumorigenesis as it also participates in many other normal cellular processes like embryonic development, wound healing, tissue regeneration, and fibrosis [127, 134-136]. However, when EMT is reactivated (partially or fully) in cancer cells indiscriminately, these cells acquire mobility, a mesenchymal feature that augments invasiveness and metastasis of cancer cells $[128,136,137]$. Through extensive research of in vitro cancer cell-based models, it has been found that the hallmarks of EMT are overexpression of EMT regulatory transcriptional factors such as the family of zincfinger proteins (SNAIL)1/2 and Twist-related proteins (TWIST)1/2 as well as dysregulation of key proteins like E-cadherin, N-cadherin, vimentin, and $\beta$-catenin (Figure 2) $[128,136,138,139]$. The anti-metastatic effects of BD have only been studied in human TNBC and osteosarcoma. In a study by Luo et al. [30], have used low concentrations of $\mathrm{BD}(1 \mu \mathrm{M}$ to $4 \mu \mathrm{M})$ to determine its effect on the migration and invasion of breast cancer cells. This study displayed that MDA-MB-231 cells treated with BD had lowered migratory and invasive capabilities which varied in a dose-dependent manner [30]. It was also observed that loss of E-cadherin and overexpression of vimentin and $\beta$-catenin was abrogated in cells treated with BD varying in a dose-dependent manner, suggesting that the EMT program was successfully reversed, if not partially, in MDA-MB-231 cells (Figure 2). In another study, it was reported that BD-treated osteosarcoma cell lines MNNG/HOS and U2-OS displayed reduced expression of N-cadherin, MMP-2, and MMP-9, all of which are EMT biomarkers and play important roles in tumorigenesis [47]. Wang et al. [47], took it one step further and exemplified the partial involvement of the JAK2/STAT3 signaling pathway in BD-induced inhibition of osteosarcoma growth and migration. Constitutively active STAT3 has been shown to induce tumor formation in osteosarcoma. In both cell lines, phosphorylated JAK2 and STAT3 was decreased while phosphatase SHP1, a negative regulator of STAT3, was upregulated, indicating that BD reversed the constitutive activation of the JAK2/STAT3 signaling pathway in the osteosarcoma cell lines [47]. 
Although the anti-metastatic effects of BD seem promising, both studies only demonstrated the effect of BD against their respective cancer cell lines in vitro. In vitro, modeling can model certain aspects of tumorigenesis such as cellular migration and invasion, but it suffers from certain inherent limitations as it lacks the complete physiological interactions in vivo. In order to fully assess the anti-metastatic effects of BD, in vivo animal models should be carefully examined before concluding.

\section{Potential anti-inflammatory effects of BD}

Chronic inflammation has been hailed as one of the significant hallmarks of cancer progression and tumorigenesis. Through chronic inflammation, a conducive tumor microenvironment is formed from the plethora of inflammatory cells and cytokines available in the vicinity, promoting tumor survival and proliferation[140-142]. One of the prominent players involved in the inflammation-tumorigenesis crosstalk is nuclear factor- $\mathrm{\kappa B}(\mathrm{NF}-\mathrm{\kappa B})$. NF- $\mathrm{KB}$ is a nuclear transcription factor that regulates genes responsible for the body's immune responses as well as other essential physiological responses like inflammation, cell proliferation, and apoptosis [143,144]. BD has been observed to be the second most potent inhibitor of inflammation in rodents, with the first being brusatol, another quassinoid extracted from Brucea javanica as well [145]. Recently, the anti-inflammatory properties of Brucea javanica oil emulsion (BJOE) in dextram sulfate sodium-induced ulcerative colitis has been investigated [146]. Oleic acid and linoleic acid have been found to have major components of BJOE, and that both oleic acid and linoleic acid have been shown to display anti-inflammatory properties. Despite BD not being a component of BJOE, it was found that the NF- $\mathrm{kB}$ pathway was significantly attenuated via inhibition of NF- $\mathrm{kB}$ and nuclear factor of kappa light polypeptide

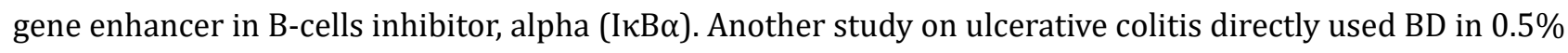
sodium carboxymethyl cellulose solution and BD delivered using a self-nanoemulsifying drug delivery system (BD-SNEDDS) $[146,147]$. It was reported that in addition to attenuating the NF- $\kappa B$ pathway, BD was also capable of suppressing cyclooxygenase-2, an enzyme implicated in inflammation [18]. In a separate study on Parkinson's disease, BD was also found to inhibit inflammation as well albeit via the nuclear factor erythroid 2-related factor 2 (Nrf2) signaling pathway.

Although there is currently no evidence of BD's anti-inflammatory properties in cancer models, given the highly intertwined nature of NF- $\kappa B$ in the cross-talk between inflammation and cancer, it would therefore not be surprising if BD exhibited anti-inflammatory properties in inhibiting tumorigenesis and cancer development.

\section{Pharmacokinetics, toxicity and metabolism}

As mentioned previously, BD was explored as an anti-inflammatory agent to ulcerative colitis. The pharmacokinetics of BD-suspension in $0.5 \%$ sodium carboxymethyl cellulose solution was only established in the same ulcerative colitis murine model study relative to BD-SNEDDS. The concentration used for both BD and BD-SNEDDS was $3.0 \mathrm{mg} / \mathrm{kg}^{-1}$.

As established by the aforementioned BD research, all of them noted non-significant toxicity against normal cell lines in vitro (cell viability maintained) and in vivo (maintenance of growth parameters like weight). There is currently no study indicating any other toxicity, allergies, or contraindications when using BD. Drug metabolism of BD in vitro and in vivo and whether any adverse metabolites are produced remain unknown.

\section{Clinical application of BD}

Currently, BD is commonly used with other quassinoids and bioactive compounds within BJOE as adjuvant therapy to chemotherapy and radiotherapy of various malignancies in China, some of which include brain cancers, gastrointestinal cancers, and urological malignancies. BJOE is administered for its anticancer effects and/or attenuation of side effects from conventional cancer treatment [26]. Clinical trials involving BD as a stand-alone treatment option or adjuvant therapy had yet to be conducted. Further research on its clinical use should, therefore, be conducted to fully ascertain its inhibitory effects on tumorigenesis in human patients. 


\section{Conclusion and future directions}

This review highlights the antineoplastic effects of BD in various cancer models. The BD has been demonstrated to exhibit anti-proliferative and pro-apoptotic effects against various cancer cell lines via inhibition of the key regulatory signaling pathways like PI3K/AKT/mTOR, JAK/STAT, JAG1/Notch. Also, there were promising metastatic regulatory effects on breast cancer and osteosarcoma cell lines and potential anti-inflammatory effects. However, there is still much to be learned about the exact molecular targets of BD as many of the studies were mainly concerned with finding its antineoplastic effects and not its direct molecular target per se. Given the mounting evidence of BD efficacy against various cancer cell lines in vitro and in vivo, BD could potentially be considered as yet another novel anticancer drug and a future candidate for clinical trials and development. In the future, the combination of BD with standard chemotherapeutic drugs may be explored for developing better treatment options with the aim of long-term disease-free survival.

\section{Abbreviations}

AKT: protein kinase B

ASK-1: apoptosis signal-regulating kinase 1

BAX: Bcl-2 associated protein

Bcl-2: B-cell lymphoma 2

BD: bruceine $\mathrm{D}$

BD-SNEDDS: BD-loaded self-nanoemulsifying drug delivery system

BD-suspension: BD suspended in $0.5 \%$ sodium carboxymethyl cellulose solution as control

BJOE: Brucea javanica oil emulsion

CD133: prominin-1

CDK2: cyclin-dependent kinase 2

CDK4: cyclin-dependent kinase 4

CSCs: cancer stem cells

CUGBP2: Elav-like family member 2

cyt c: cytochrome c

EMT: epithelial-mesenchymal transition

ERK: extracellular signal-regulated kinase

HCC: hepatocellular carcinoma

JAG1: Jagged1

JAK: Janus kinase

JNK: c-Jun N-terminal kinase

LC3-II: autophagy marker

MAPK: mitogen-activated protein kinases

Mcl-1: myeloid cell leukemia 1

MEK: mitogen-activated protein kinase kinase

miR-95: microRNA-95

MMP2: matrix metalloproteinase-2 (gelatinase A)

MMP9: matrix metallopeptidase 9 (gelatinase B)

mTOR: mammalian target of Rapamycin

Nanog: Homeobox protein NANOG

NF-кB: Nuclear factor- $\kappa \mathrm{B}$

NICD: the cleaved intracellular domain of Notch receptor 
NSCLC: non-small cell lung cancer

Oct-4: octamer-binding transcription factor 4

p38-MAPK: p38 mitogen-activated protein kinases

pAKT: phosphorylated protein kinase B

PARP: poly (ADP-ribose) polymerase

pERK: phosphorylated extracellular signal-regulated kinase

PI3K: phosphatidylinositol 3-kinase

pJNK: phosphorylated c-Jun N-terminal kinase

pSTAT3: phosphorylated signal transducer and activator of transcription 3

Ras: Ras protein family

ROS: reactive oxygen species

SHP1: Tyrosine-protein phosphatase non-receptor type 6

SOX2: SRY (sex-determining region Y)-box 2

STAT: signal transducers and activator of transcription

TNBC: triple-negative breast cancer

Um: mitochondrial membrane potential

\section{Declarations}

\section{Author contributions}

The concept and design of this manuscript are conceived by ZWS and MG. ZWS, AKP, and MG wrote and revised the manuscript, presented the concept, created figures, tables. All authors have read the manuscript and agreed to the published version of the manuscript.

\section{Conflicts of interest}

The authors declare that they have no conflicts of interest.

\section{Ethical approval}

Not applicable.

\section{Consent to participate}

Not applicable.

\section{Consent to publication}

Not applicable.

Availability of data and materials

Not applicable.

\section{Funding}

This work was supported by the Department of Biotechnology (DBT), under its Ramalingaswami Fellowship number BT/RLF/Re-entry/24/2014 and Science and Engineering Research Board under its ECRA scheme (SERB File No. ECR/2016/001519) award to Dr. Manoj Garg. The sponsor(s) have no role in designing, analysis, interpretation and writing. 


\section{Copyright}

(C) The Author(s) 2020.

\section{References}

1. Blackadar CB. Historical review of the causes of cancer. World J Clin Oncol. 2016;7:54-86.

2. Sarkar S, Horn G, Moulton K, Oza A, Byler S, Kokolus S, et al. Cancer development, progression, and therapy: an epigenetic overview. Int J Mol Sci. 2013;14:21087-113.

3. Kirtonia A, Gala K, Fernandes SG, Pandya G, Pandey AK, Sethi G, et al. Repurposing of drugs: an attractive pharmacological strategy for cancer therapeutics. Semin Cancer Biol. 2020;[Epub ahead of print].

4. Garg M, Braunstein G, Koeffler HP. LAMC2 as a therapeutic target for cancers. Expert Opin Ther Targets. 2014;18:979-82.

5. Hanahan D, Weinberg RA. Hallmarks of cancer: the next generation. Cell. 2011;144:646-74.

6. Bray F, Ferlay J, Soerjomataram I, Siegel RL, Torre LA, Jemal A. Global cancer statistics 2018: GLOBOCAN estimates of incidence and mortality worldwide for 36 cancers in 185 countries. CA Cancer J Clin. 2018;68:394-424.

7. Nurgali K, Jagoe RT, Abalo R. Editorial: adverse effects of cancer chemotherapy: anything new to improve tolerance and reduce sequelae? Front Pharmacol. 2018;9:245.

8. Kashyap D, Tuli HS, Yerer MB, Sharma A, Sak K, Srivastava S, et al. Natural product-based nanoformulations for cancer therapy: opportunities and challenges. Semin Cancer Biol. 2019; [Epub ahead of print].

9. Shanmugam MK, Warrier S, Kumar AP, Sethi G, Arfuso F. Potential role of natural compounds as antiangiogenic agents in cancer. Curr Vasc Pharmacol. 2017;15:503-19.

10. Tewari D, Nabavi SF, Nabavi SM, Sureda A, Farooqi AA, Atanasov AG, et al. Targeting activator protein 1 signaling pathway by bioactive natural agents: possible therapeutic strategy for cancer prevention and intervention. Pharmacol Res. 2018;128:366-75.

11. Wong ALA, Hirpara JL, Pervaiz S, Eu JQ Sethi G, Goh BC. Do STAT3 inhibitors have potential in the future for cancer therapy? Expert Opin Investig Drugs. 2017;26:883-7.

12. Ramachandran L, Manu KA, Shanmugam MK, Li F, Siveen KS, Vali S, et al. Isorhamnetin inhibits proliferation and invasion and induces apoptosis through the modulation of peroxisome proliferatoractivated receptor gamma activation pathway in gastric cancer. J Biol Chem. 2012;287:38028-40.

13. Prasannan R, Kalesh KA, Shanmugam MK, Nachiyappan A, Ramachandran L, Nguyen AH, et al. Key cell signaling pathways modulated by zerumbone: role in the prevention and treatment of cancer. Biochem Pharmacol. 2012;84:1268-76.

14. Subramaniam S, Selvaduray KR, Radhakrishnan AK. Bioactive compounds: natural defense against cancer? Biomolecules. 2019;9:758.

15. Yun CW, Lee SH. The roles of autophagy in cancer. Int J Mol Sci. 2018;19:3466.

16. Ye QM, Bai LL, Hu SZ, Tian HY, Ruan LJ, Tan YF, et al. Isolation, chemotaxonomic significance and cytotoxic effects of quassinoids from Brucea javanica. Fitoterapia. 2015;105:66-72.

17. Yarla NS, Bishayee A, Sethi G, Reddanna P, Kalle AM, Dhananjaya BL, et al. Targeting arachidonic acid pathway by natural products for cancer prevention and therapy. Semin Cancer Biol. 2016;40-41:48-81.

18. Yang Y, Kong F, Ding Q Cai Y, Hao Y, Tang B. Bruceine D elevates Nrf2 activation to restrain Parkinson's disease in mice through suppressing oxidative stress and inflammatory response. Biochem Biophys Res Commun. 2020;526:1013-20.

19. Yang SF, Weng CJ, Sethi G, Hu DN. Natural bioactives and phytochemicals serve in cancer treatment and prevention. Evid Based Complement Alternat Med. 2013;2013:698190.

20. Kim C, Kim B. Anti-cancer natural products and their bioactive compounds inducing ER stress-mediated apoptosis: a review. Nutrients. 2018;10:1021. 
21. Teixeira TR, Santos GSD, Armstrong L, Colepicolo P, Debonsi HM. Antitumor potential of seaweed derived-endophytic fungi. Antibiotics (Basel). 2019;8:205.

22. Zhang QY, Wang FX, Jia KK, Kong LD. Natural product interventions for chemotherapy and radiotherapyinduced side effects. Front Pharmacol. 2018;9:1253.

23. Newman DJ, Cragg GM. Natural products as sources of new drugs from 1981 to 2014. J Nat Prod. 2016;79:629-61.

24. de la Torre BG, Albericio F. The pharmaceutical industry in 2017. An analysis of FDA drug approvals from the perspective of molecules. Molecules. 2018;23:533.

25. Kim IH, Takashima S, Hitotsuyanagi Y, Hasuda T, Takeya K. New quassinoids, javanicolides C and D and javanicosides B--F, from seeds of Brucea javanica. J Nat Prod. 2004;67:863-8.

26. Yan Z, Guo GF, Zhang B. Research of Brucea javanica against cancer. Chin J Integr Med. 2017;23:153-60.

27. Dong SH, Liu J, Ge YZ, Dong L, Xu CH, Ding J, et al. Chemical constituents from Brucea javanica. Phytochemistry. 2013;85:175-84.

28. Fan J, Ren D, Wang J, Liu X, Zhang H, Wu M, et al. Bruceine D induces lung cancer cell apoptosis and autophagy via the ROS/MAPK signaling pathway in vitro and in vivo. Cell Death Dis. 2020;11:126.

29. Lau ST, Lin ZX, Liao Y, Zhao M, Cheng CH, Leung PS. Bruceine D induces apoptosis in pancreatic adenocarcinoma cell line PANC-1 through the activation of p38-mitogen activated protein kinase. Cancer Lett. 2009;281:42-52.

30. Luo C, Wang Y, Wei C, Chen Y, Ji Z. The anti-migration and anti-invasion effects of Bruceine D in human triple-negative breast cancer MDA-MB-231 cells. Exp Ther Med. 2020;19:273-9.

31. Shen JG, Zhang ZK, Wu ZJ, Ouyang MA, Xie LH, Lin QY. Antiphytoviral activity of bruceine-D from Brucea javanica seeds. Pest Manag Sci. 2008;64:191-6.

32. Yan XH, Chen J, Di YT, Fang X, Dong JH, Sang P, et al. Anti-tobacco mosaic virus (TMV) Quassinoids from Brucea javanica (L.) Merr. J Agric Food Chem. 2010;58:1572-7.

33. Cai SJ, Liu Y, Han S, Yang C. Brusatol, an NRF2 inhibitor for future cancer therapeutic. Cell Biosci. 2019;9:45.

34. Eigebaly SA, Hall IH, Lee KH, Sumida Y, Imakura Y, Wu RY. Antitumor agents. XXXV: effects of brusatol, bruceoside A, and bruceantin on P-388 lymphocytic leukemia cell respiration. J Pharm Sci. 1979;68:887-90.

35. Xu JP. Cancer inhibitors from Chinese natural medicines. Boca Raton: CRC Press; 2017.

36. Li Z, Ruan JY, Sun F, Yan JJ, Wang JL, Zhang ZX, et al. Relationship between structural characteristics and plant sources along with pharmacology research of quassinoids. chem pharm bull (Tokyo). 2019;67:654-65.

37. Lau ST, Lin ZX, Leung PS. Role of reactive oxygen species in brucein D-mediated p38-mitogen-activated protein kinase and nuclear factor-kappaB signalling pathways in human pancreatic adenocarcinoma cells. Br J Cancer. 2010;102:583-93.

38. Zhao X, Yang Y, Xu J, Luo Y, Xin Y, Wang Y. Downregulation of microRNA-95-3p suppresses cell growth of osteosarcoma via CDKN1A/p21 expression. Oncol Rep. 2018;39:289-97.

39. Pfeffer CM, Singh ATK. Apoptosis: a target for anticancer therapy. Int J Mol Sci. 2018;19:448.

40. Tian X, Li Y, Shen Y, Li Q, Wang Q, Feng L. Apoptosis and inhibition of proliferation of cancer cells induced by cordycepin. Oncol Lett. 2015;10:595-9.

41. Rajendran P, Li F, Shanmugam MK, Vali S, Abbasi T, Kapoor S, et al. Honokiol inhibits signal transducer and activator of transcription-3 signaling, proliferation, and survival of hepatocellular carcinoma cells via the protein tyrosine phosphatase SHP-1. J Cell Physiol. 2012;227:2184-95.

42. Tan B, Huang Y, Lan L, Zhang B, Ye L, Yan W, et al. Bruceine D induces apoptosis in human non-small cell lung cancer cells through regulating JNK pathway. Biomed Pharmacother. 2019;117:109089. 
43. Xie JH, Lai ZQ, Zheng XH, Xian YF, Li Q Ip SP, et al. Apoptosis induced by bruceine D in human nonsmallcell lung cancer cells involves mitochondrial ROSmediated death signaling. Int J Mol Med. 2019;44:2015-26.

44. Zhang JY, Lin MT, Tung HY, Tang SL, Yi T, Zhang YZ, et al. Bruceine D induces apoptosis in human chronic myeloid leukemia K562 cells via mitochondrial pathway. Am J Cancer Res. 2016;6:819-26.

45. Cheng Z, Yuan X, Qu Y, Li X, Wu G, Li C, et al. Bruceine D inhibits hepatocellular carcinoma growth by targeting beta-catenin/jagged1 pathways. Cancer Lett. 2017;403:195-205.

46. Xiao Z, Ching Chow S, Han Li C, Chun Tang S, Tsui SK, Lin Z, et al. Role of microRNA-95 in the anticancer activity of Brucein D in hepatocellular carcinoma. Eur J Pharmacol. 2014;728:141-50.

47. Wang S, Hu H, Zhong B, Shi D, Qing X, Cheng C, et al. Bruceine D inhibits tumor growth and stem cell-like traits of osteosarcoma through inhibition of STAT3 signaling pathway. Cancer Med. 2019;8:7345-58.

48. Gerl R, Vaux DL. Apoptosis in the development and treatment of cancer. Carcinogenesis. 2005;26:263-70.

49. Johnson GL, Lapadat R. Mitogen-activated protein kinase pathways mediated by ERK, JNK, and p38 protein kinases. Science. 2002;298:1911-2.

50. Wada T, Penninger JM. Mitogen-activated protein kinases in apoptosis regulation. Oncogene. 2004;23:2838-49.

51. Dhanasekaran DN, Reddy EP. JNK signaling in apoptosis. Oncogene. 2008;27:6245-51.

52. Pecina-Slaus N. Wnt signal transduction pathway and apoptosis: a review. Cancer Cell Int. 2010;10:22.

53. Wang C, Kar S, Lai X, Cai W, Arfuso F, Sethi G, et al. Triple negative breast cancer in Asia: an insider's view. Cancer Treat Rev. 2018;62:29-38.

54. Jia LY, Shanmugam MK, Sethi G, Bishayee A. Potential role of targeted therapies in the treatment of triplenegative breast cancer. Anticancer Drugs. 2016;27:147-55.

55. Waks AG, Winer EP. Breast cancer treatment: a review. JAMA. 2019;321:288-300.

56. Aysola K, Desai A, Welch C, Xu J, Qin Y, Reddy V, et al. Triple negative breast cancer - an overview. Hereditary Genet. 2013;2013:001.

57. Kansara S, Pandey V, Lobie PE, Sethi G, Garg M, Pandey AK. Mechanistic involvement of long non-coding RNAs in oncotherapeutics resistance in triple-negative breast cancer. Cells. 2020;6:E511.

58. Lebert JM, Lester R, Powell E, Seal M, McCarthy J. Advances in the systemic treatment of triple-negative breast cancer. Curr Oncol. 2018;25:S142-50.

59. Mehanna J, Haddad FG, Eid R, Lambertini M, Kourie HR. Triple-negative breast cancer: current perspective on the evolving therapeutic landscape. Int J Womens Health. 2019;11:431-7.

60. Wang H, Duan L, Zou Z, Li H, Yuan S, Chen X, et al. Activation of the PI3K/Akt/mTOR/p70S6K pathway is involved in S100A4-induced viability and migration in colorectal cancer cells. Int J Med Sci. 2014;11:841-9.

61. Fresno Vara JA, Casado E, de Castro J, Cejas P, Belda-Iniesta C, González-Barón M. PI3K/Akt signalling pathway and cancer. Cancer Treat Rev. 2004;30:193-204.

62. Basho RK, Gilcrease M, Murthy RK, Helgason T, Karp DD, Meric-Bernstam F, et al. Targeting the PI3K/ AKT/mTOR pathway for the treatment of mesenchymal triple-negative breast cancer: evidence from a phase 1 trial of mTOR inhibition in combination with liposomal doxorubicin and bevacizumab. JAMA Oncol. 2017;3:509-15.

63. Chien W, Sudo M, Ding LW, Sun QY, Wuensche P, Lee KL, et al. Functional genome-wide screening identifies targets and pathways sensitizing pancreatic cancer cells to dasatinib. J Cancer. 2018;9:4762-73.

64. Chien W, Ding LW, Sun QY, Torres-Fernandez LA, Tan SZ, Xiao J, et al. Selective inhibition of unfolded protein response induces apoptosis in pancreatic cancer cells. Oncotarget. 2014;5:4881-94.

65. McGuigan A, Kelly P, Turkington RC, Jones C, Coleman HG, McCain RS. Pancreatic cancer: a review of clinical diagnosis, epidemiology, treatment and outcomes. World J Gastroenterol. 2018;24:4846-61.

66. Vakoc CR, Tuveson DA. Untangling the genetics from the epigenetics in pancreatic cancer metastasis. Nat Genet. 2017;49:323-4. 
67. Canto MI, Harinck F, Hruban RH, Offerhaus GJ, Poley JW, Kamel I, et al. International cancer of the pancreas screening (CAPS) consortium summit on the management of patients with increased risk for familial pancreatic cancer. Gut. 2013;62:339-47.

68. Giroux V, Iovanna J, Dagorn JC. Probing the human kinome for kinases involved in pancreatic cancer cell survival and gemcitabine resistance. FASEB J. 2006;20:1982-91.

69. Shi X, Liu S, Kleeff J, Friess H, Büchler MW. Acquired resistance of pancreatic cancer cells towards 5-fluorouracil and gemcitabine is associated with altered expression of apoptosis-regulating genes. Oncology. 2002;62:354-62.

70. Scheithauer W, Kornek GV, Raderer M, Hejna M, Valencak J, Miholic J, et al. Phase II trial of gemcitabine, epirubicin and granulocyte colony stimulating factor in patients with advanced pancreatic adenocarcinoma. Br J Cancer. 1999;80:1797-802.

71. Matsumura Y. Polymeric micellar delivery systems in oncology. Jpn J Clin Oncol. 2008;12:793-802.

72. Lau ST, Lin ZX, Zhao M, Leung PS. Brucea javanica fruit induces cytotoxicity and apoptosis in pancreatic adenocarcinoma cell lines. Phytother Res. 2008;22:477-86.

73. Strnisková M, Barancík M, Ravingerova T. Mitogen-activated protein kinases and their role in regulation of cellular processes. Gen Physiol Biophys. 2002;21:231-55.

74. Woo CC, Hsu A, Kumar AP, Sethi G, Tan KHB, Cheng JQ. Thymoquinone inhibits tumor growth and induces apoptosis in a breast cancer xenograft mouse model: the role of p38 MAPK and ROS. PLoS One. 2013;8:e75356.

75. Dai X, Wang L, Deivasigamni A, Looi CY, Karthikeyan C, Trivedi P, et al. A novel benzimidazole derivative, MBIC inhibits tumor growth and promotes apoptosis via activation of ROS-dependent JNK signaling pathway in hepatocellular carcinoma. Oncotarget. 2017;8:12831-42.

76. Kannaiyan R, Manu KA, Chen L, Li F, Rajendran P, Subramaniam A, et al. Celastrol inhibits tumor cell proliferation and promotes apoptosis through the activation of c-Jun N-terminal kinase and suppression of PI3 K/Akt signaling pathways. Apoptosis. 2011;16:1028-41.

77. Kim SM, Kim C, Bae H, Lee JH, Baek SH, Nam D, et al. 6-Shogaol exerts anti-proliferative and pro-apoptotic effects through the modulation of STAT3 and MAPKs signaling pathways. Mol Carcinog. 2015;54:1132-46.

78. Zarubin T, Han J. Activation and signaling of the p38 MAP kinase pathway. Cell Res. 2005;15:11-8.

79. Coulthard LR, White DE, Jones DL, McDermott MF, Burchill SA. p38(MAPK): stress responses from molecular mechanisms to therapeutics. Trends Mol Med. 2009;15:369-79.

80. Lee JH, Kim C, Sethi G, Ahn KS. Brassinin inhibits STAT3 signaling pathway through modulation of PIAS-3 and SOCS-3 expression and sensitizes human lung cancer xenograft in nude mice to paclitaxel. Oncotarget. 2015;6:6386-405.

81. Lee JH, Chiang SY, Nam D, ChungWS, Lee J, Na YS, etal. Capillarisin inhibits constitutive and inducible STAT3 activation through induction of SHP-1 and SHP-2 tyrosine phosphatases. Cancer Lett. 2014;345:140-8.

82. Fridman JS, Lowe SW. Control of apoptosis by p53. Oncogene. 2003;22:9030-40.

83. Wang H, Yang Y, Sharma N, Tarasova NI, Timofeeva OA, Winkler-Pickett RT, et al. STAT1 activation regulates proliferation and differentiation of renal progenitors. Cell Signal. 2010;22:1717-26.

84. Vleugel MM, Greijer AE, Bos R, van der Wall E, van Diest PJ. c-Jun activation is associated with proliferation and angiogenesis in invasive breast cancer. Hum Pathol. 2006;37:668-74.

85. Kruidering M, Evan GI. Caspase-8 in apoptosis: the beginning of "the end"? IUBMB Life. 2000;50:85-90.

86. Braun TP, Eide CA, Druker BJ. Response and resistance to BCR-ABL1-targeted therapies. Cancer Cell. 2020;37:530-42.

87. Arora L, Kumar AP, Arfuso F, Chng WJ, Sethi G. The role of signal transducer and activator of transcription 3 (STAT3) and its targeted inhibition in hematological malignancies. Cancers (Basel). 2018;10:327. 
88. Kim C, Lee JH, Kim SH, Sethi G, Ahn KS. Artesunate suppresses tumor growth and induces apoptosis through the modulation of multiple oncogenic cascades in a chronic myeloid leukemia xenograft mouse model. Oncotarget. 2015;6:4020-35.

89. Eden RE, Coviello JM. Cancer, chronic myelogenous leukemia (CML, chronic granulocytic leukemia). In: StatPearls. Treasure Island (FL): StatPearls Publishing; 2020.

90. Jabbour E, Kantarjian H. Chronic myeloid leukemia: 2020 update on diagnosis, therapy and monitoring. Am J Hematol. 2020;95:691-709.

91. Kanojia D, Garg M, Martinez J, MT A, Luty SB, Doan NB, et al. Kinase profiling of liposarcomas using RNAi and drug screening assays identified druggable targets. J Hematol Oncol. 2017;10:173.

92. Fulda S, Debatin KM. Extrinsic versus intrinsic apoptosis pathways in anticancer chemotherapy. Oncogene. 2006;25:4798-811.

93. Fong Y, Wu CY, Chang KF, Chen BH, Chou WJ, Tseng CH, et al. Dual roles of extracellular signal-regulated kinase (ERK) in quinoline compound BPIQ-induced apoptosis and anti-migration of human non-small cell lung cancer cells. Cancer Cell Int. 2017;17:37.

94. Cagnol S, Chambard JC. ERK and cell death: mechanisms of ERK-induced cell death--apoptosis, autophagy and senescence. FEBS J. 2010;277:2-21.

95. Lee JH, Mohan CD, Basappa S, Rangappa S, Chinnathambi A, Alahmadi TA, et al. The IkappaB kinase inhibitor ACHP targets the STAT3 signaling pathway in human non-small cell lung carcinoma cells. Biomolecules. 2019;9:875.

96. Hayano T, Garg M, Yin D, Sudo M, Kawamata N, Shi S, et al. SOX7 is down-regulated in lung cancer. J Exp Clin Cancer Res. 2013;32:17.

97. Lee JH, Chinnathambi A, Alharbi SA, Shair OHM, Sethi G, Ahn KS. Farnesol abrogates epithelial to mesenchymal transition process through regulating Akt/mTOR pathway. Pharmacol Res. 2019;150:104504.

98. Jung YY, Shanmugam MK, Narula AS, Kim C, Lee JH, Namjoshi OA, et al. Oxymatrine attenuates tumor growth and deactivates STAT5 signaling in a lung cancer xenograft model. Cancers (Basel). 2019;11:49.

99. Zappa C, Mousa SA. Non-small cell lung cancer: current treatment and future advances. Transl Lung Cancer Res. 2016;5:288-300.

100. Molina JR, Yang P, Cassivi SD, Schild SE, Adjei AA. Non-small cell lung cancer: epidemiology, risk factors, treatment, and survivorship. Mayo Clin Proc. 2008;83:584-94.

101. Dhanasekaran DN, Reddy EP. JNK-signaling: a multiplexing hub in programmed cell death. Genes Cancer. 2017;8:682-94.

102. Kirtonia A, Sethi G, Garg M. The multifaceted role of reactive oxygen species in tumorigenesis. Cell Mol Life Sci. 2020;[Epub ahead of print].

103. Aggarwal V, Tuli HS, Varol A, Thakral F, Yerer MB, Sak K, et al. Role of reactive oxygen species in cancer progression: molecular mechanisms and recent advancements. Biomolecules. 2019;9:735.

104. Kansara M, Teng MW, Smyth MJ, Thomas DM. Translational biology of osteosarcoma. Nat Rev Cancer. 2014;14:722-35.

105. Brown HK, Tellez-Gabriel M, Heymann D.Cancerstem cells in osteosarcoma.Cancer Lett. 2017;386:189-95.

106. Sneha S, Nagare RP, Sidhanth C, Krishnapriya S, Garg M, Ramachandran B, et al. The hedgehog pathway regulates cancer stem cells in serous adenocarcinoma of the ovary. Cell Oncol (Dordr). 2020;[Epub ahead of print].

107. Peng L, Jiang D. Resveratrol eliminates cancer stem cells of osteosarcoma by STAT3 pathway inhibition. PLoS One. 2018;13:e0205918.

108. Bindhya S, Sidhanth C, Shabna A, Krishnapriya S, Garg M, Ganesan TS. Induced pluripotent stem cells: a new strategy to model human cancer. Int J Biochem Cell Biol. 2019;107:62-8. 
109. Sethi G, Chatterjee S, Rajendran P, Li F, Shanmugam MK, Wong KF, et al. Inhibition of STAT3 dimerization and acetylation by garcinol suppresses the growth of human hepatocellular carcinoma in vitro and in vivo. Mol Cancer. 2014;13:66.

110. Mohan CD, Bharathkumar H, Bulusu KC, Pandey V, Rangappa S, Fuchs JE, et al. Development of a novel azaspirane that targets the Janus kinase-signal transducer and activator of transcription (STAT) pathway in hepatocellular carcinoma in vitro and in vivo. J Biol Chem. 2014;289:34296-307.

111. Siveen KS, Ahn KS, Ong TH, Shanmugam MK, Li F, Yap WN, et al. Y-tocotrienol inhibits angiogenesisdependent growth of human hepatocellular carcinoma through abrogation of AKT/mTOR pathway in an orthotopic mouse model. Oncotarget. 2014;5:1897-911.

112. Subramaniam A, Shanmugam MK, Ong TH, Li F, Perumal E, Chen L, et al. Emodin inhibits growth and induces apoptosis in an orthotopic hepatocellular carcinoma model by blocking activation of STAT3. Br J Pharmacol. 2013;170:807-21.

113. Dai X, Ahn KS, Kim C, Siveen KS, Ong TH, Shanmugam MK, et al. Ascochlorin, an isoprenoid antibiotic inhibits growth and invasion of hepatocellular carcinoma by targeting STAT3 signaling cascade through the induction of PIAS3. Mol Oncol. 2015;9:818-33.

114. Mastron JK, Siveen KS, Sethi G, Bishayee A. Silymarin and hepatocellular carcinoma: a systematic, comprehensive, and critical review. Anticancer Drugs. 2015;26:475-86.

115. Li D, Masiero M, Banham AH, Harris AL. The notch ligand JAGGED1 as a target for anti-tumor therapy. Front Oncol. 2014;4:254.

116. Sethi N, Dai X, Winter CG, Kang Y. Tumor-derived JAGGED1 promotes osteolytic bone metastasis of breast cancer by engaging notch signaling in bone cells. Cancer Cell. 2011;19:192-205.

117. Peng Y, Croce CM. The role of microRNAs in human cancer. Signal Transduct Target Ther. 2016;1:15004.

118. Ye J, Yao Y, Song Q Li S, Hu Z, Yu Y, et al. Up-regulation of miR-95-3p in hepatocellular carcinoma promotes tumorigenesis by targeting p21 expression. Sci Rep. 2016;6:34034.

119. Fan B, Jiao BH, Fan FS, Lu SK, Song J, Guo CY, et al. Downregulation of miR-95-3p inhibits proliferation, and invasion promoting apoptosis of glioma cells by targeting CELF2. Int J Oncol. 2015;47:1025-33.

120. Subramaniam D, Natarajan G, Ramalingam S, Ramachandran I, May R, Queimado L, et al. Translation inhibition during cell cycle arrest and apoptosis: Mcl-1 is a novel target for RNA binding protein CUGBP2. Am J Physiol Gastrointest Liver Physiol. 2008;294:G1025-32.

121. Shinde A, Paez JS, Libring S, Hopkins K, Solorio L, Wendt MK. Transglutaminase-2 facilitates extracellular vesicle-mediated establishment of the metastatic niche. Oncogenesis. 2020;9:16.

122. Shinde A, Libring S, Alpsoy A, Abdullah A, Schaber JA, Solorio L, et al. Autocrine fibronectin inhibits breast cancer metastasis. Mol Cancer Res. 2018;16:1579-89.

123. Wee I, Syn N, Sethi G, Goh BC, Wang L. Role of tumor-derived exosomes in cancer metastasis. Biochim Biophys Acta Rev Cancer. 2019;1871:12-9.

124. Shinde A, Hardy SD, Kim D, Akhand SS, Jolly MK, Wang WH, et al. Spleen tyrosine kinase-mediated autophagy is required for epithelial-mesenchymal plasticity and metastasis in breast cancer. Cancer Res. 2019;79:1831-43.

125. Chiang AC, Massagué J. Molecular basis of metastasis. N Engl J Med. 2008;359:2814-23.

126. Fidler IJ. The pathogenesis of cancer metastasis: the 'seed and soil' hypothesis revisited. Nat Rev Cancer. 2003;3:453-8.

127. Loh CY, Chai JY, Tang TF, Wong WF, Sethi G, Shanmugam MK, et al. The E-cadherin and N-cadherin switch in epithelial-to-mesenchymal transition: signaling, therapeutic implications, and challenges. Cells. 2019;8:1118.

128. Valastyan S, Weinberg RA. Tumor metastasis: molecular insights and evolving paradigms. Cell. 2011;147:275-92. 
129. Hunter KW, Crawford NP, Alsarraj J. Mechanisms of metastasis. Breast Cancer Res. 2008;10 Suppl 1:S2.

130. Shinde A, Wilmanski T, Chen H, Teegarden D, Wendt MK. Pyruvate carboxylase supports the pulmonary tropism of metastatic breast cancer. Breast Cancer Res. 2018;20:76.

131. Hardy SD, Shinde A, Wang WH, Wendt MK, Geahlen RL. Regulation of epithelial-mesenchymal transition and metastasis by TGF-beta, P-bodies, and autophagy. Oncotarget. 2017;8:103302-14.

132. Libring S, Shinde A, Chanda MK, Nuru M, George H, Saleh AM, et al. The dynamic relationship of breast cancer cells and fibroblasts in fibronectin accumulation at primary and metastatic tumor sites. Cancers (Basel). 2020;12:1270.

133. Wilmanski T, Zhou X, Zheng W, Shinde A, Donkin SS, Wendt M, et al. Inhibition of pyruvate carboxylase by 1alpha,25-dihydroxyvitamin D promotes oxidative stress in early breast cancer progression. Cancer Lett. 2017;411:171-81.

134. Ko JH, Nam D, Um JY, Jung SH, Sethi G, Ahn KS. Bergamottin suppresses metastasis of lung cancer cells through abrogation of diverse oncogenic signaling cascades and epithelial-to-mesenchymal transition. Molecules. 2018;23:1601.

135. Cheng JT, Wang L, Wang H, Tang FR, Cai WQ, Sethi G, et al. Insights into biological role of lncRNAs in epithelial-mesenchymal transition. Cells. 2019;8:1178.

136. Nieto MA, Huang RY, Jackson RA, Thiery JP. EMT: 2016. Cell. 2016;166:21-45.

137. Brabletz T, Kalluri R, Nieto MA, Weinberg RA. EMT in cancer. Nat Rev Cancer. 2018;18:128-34.

138. Vergara D, Simeone P, Franck J, Trerotola M, Giudetti A, Capobianco L, et al. Translating epithelial mesenchymal transition markers into the clinic: novel insights from proteomics. EuPA Open Proteom. 2016;10:31-41.

139. Nakajima S, Doi R, Toyoda E, Tsuji S, Wada M, Koizumi M, et al. N-cadherin expression and epithelialmesenchymal transition in pancreatic carcinoma. Clin Cancer Res. 2004;10:4125-33.

140. Chen C. COX-2's new role in inflammation. Nat Chem Biol. 2010;6:401-2.

141. Coussens LM, Werb Z. Inflammation and cancer. Nature. 2002;420:860-7.

142. Crusz SM, Balkwill FR. Inflammation and cancer: advances and new agents. Nat Rev Clin Oncol. 2015;12:584-96.

143. Park MH, Hong JT. Roles of NF-kappaB in cancer and inflammatory diseases and their therapeutic approaches. Cells. 2016;5:15.

144. Puar YR, Shanmugam MK, Fan L, Arfuso F, Sethi G, Tergaonkar V. Evidence for the involvement of the master transcription factor NF-kappaB in cancer initiation and progression. Biomedicines. 2018;6:82.

145. Hall IH, Lee KH, Imakura Y, Okano M, Johnson A. Anti-inflammatory agents III: structure-activity relationships of brusatol and related quassinoids. J Pharm Sci. 1983;72:1282-4.

146. Huang YF, Zhou JT, Qu C, Dou YX, Huang QH, Lin ZX, et al. Anti-inflammatory effects of Brucea javanica oil emulsion by suppressing NF-kappaB activation on dextran sulfate sodium-induced ulcerative colitis in mice. J Ethnopharmacol. 2017;198:389-98.

147. Dou YX, Zhou JT, Wang TT, Huang YF, Chen VP, Xie YL, et al. Self-nanoemulsifying drug delivery system of bruceine D: a new approach for anti-ulcerative colitis. Int J Nanomedicine. 2018;13:5887-907. 